\title{
TA'AWUN PATTERN OF GOVERNANCE OF HAJJ FUNDS IN THE MINISTRY OF RELIGION OF THE REPUBLIC OF INDONESIA
}

\author{
Nursanita \\ STEI Jakarta \& Doctor Degree Program in Accounting, Faculty of Economics and Business, \\ University of Brawijaya, Indonesia \\ UntiLudigdo, GugusIrianto, ZakiBaridwan \\ University of Brawijaya, Indonesia
}

\begin{abstract}
The purpose of this study is to understand the implementation of Hajj fund management in the Ministry of Religion of the Republic of Indonesia, especially in the Sub-directorate of Haj Management Body (BPIH). The hajj fund was questioned by the community because of the lack of clarity in its management and indications of fraud and the suspicion was proven by the arrest of the Minister of Religion as the mandate holder of the Hajj fund in the Indonesian Ministry of Religion in 2006 for violating Law No.31 of 1999. So far, the reform of governance of Hajj funds has not shown any significant results.

This study uses an interpretive method, specifically an ethnomethodology approach to reveal the routines in which actors in the Sub-directorate of BPIH in the Indonesian Ministry of Religion run or practice their culture (Garfinkel, 1967). The data was collected by interview and observations.

This study found a pattern of ta'awun in the governance of the utilization of Hajj funds. The utilization of the Hajj fund is permitted by the MUI fatwa, but the pilgrims do not get a return because of the large number of the pilgrims scattered in all over Indonesia. The funds used to finance the Hajj pilgrimage are from direct cost and indirect cost. These terms are of different definitions used in accountancy as they are only used in the Ministry of Religion. Direct cost is funds deposited by pilgrims while indirect costs are funds from the optimization of deposit funds and efficient hajj. In practice, the money paid by pilgrims at the beginning of registration is only to get a seat.

In the year of the departure, they have to pay the rest of the cost (the direct cost) for the BPIH for the year of the departure as determined by the Ministry of Religion and the House of Representatives. In the implementation of the hajj pilgrimage the lack of funds using indirect cost funds is the result of optimizing the hajj funds collected by the Ministry of Religion both from the deposit of pilgrims who have not departed yet and from the results of the efficiency of the previous year's hajj funds. Actors in sub-ectorate of BPIH as Hajj fund managers agree that the use of indirect funds is indeed very much needed and is a ta'awun subsidy or helping each other, in this case fellow prospective pilgrims.
\end{abstract}

Keywords: hajj funds, ta'awun, subsidies, transparency, Haj Management Body (BPIH) cost, Ministry of Religion of the Republic of Indonesia. 


\section{Introduction}

Hajj funds are money collected from the initial deposit of pilgrims and money obtained from the efficiency of the cost of administering the Hajj and from other sources that are in accordance with the present regulations. Hajj funds are questioned by the public because of the lack of clarity in their management and indications of fraud and the suspicion is proven by the arrest of the Minister of Religion as the holder of the Hajj fund in the Ministry of Religion of the Republic of Indonesia in 2006 for violating Law No.31 of 1999.

Prasojo and Kurniawan (2008) conclude that good governance can play a role in improving good governance. Stone and Ostower (2007) examining governance in nonprofit companies conclude that good governance needs to involve many actors. The relationship between the organization and the public gives a significant contribution to the organization; therefore, it must be maintained properly. The governance will eventually affect the accountability of the non-profit organizations.Another public sector governance research conducted by Sorensen and Torfing (2009) states that forming a network of public actors with the private sector can increase the participation of stakeholders and public policy makers. On the other hand, if this relationship is not good then the performance of the company or public entity will also be damaged. A good relationship with regulators can build strategic potential that will bring good effect to the transparency and accountability of public sector institutions. This research is in line with the research of Irawan (2008) which conclude that the involvement of the wider community to create a democratic government would have an impact on improving government performance.

Most empirical research on factors that influence governance which have been mostly done focused on understanding of the principles of governance itself. This understanding will affect organizational commitment which then will increase the performance of the entity if supported by good internal control (Taufik and Kemala, 2013). Hartley (2010) examined entities in the public sector and found that developing an understanding of innovation in public sector governance reflected the context and specific objectives of the public sector. Sari and Raharja (2013) prove that internal auditors play a significant role in good governance in the Public Service Agency (BLU). This finding is supported by Nugroho (2010) who says that internal auditors play a role in increasing transparency and accountability can improve performance in public sector companies.

Bovaird (2005) proves the strength of stakeholders in the network society influences governance in the public sector (governance in the shadow of government). Internet and sophisticated computer technology make it possible to set up self-regulating policies, especially for routine and service systems. Bovaird named it governance without government. Other factors in the accounting system and cultural differences in the communities in which research is conducted affect governance (Choudhury, 2006; Wallaced et al., 1994; Wagner and Gooding, 1999). Governance is a mechanism that consists of structures and processes that determine how delegation of authority and responsibility and decision-making are carried out by an institution (Chapra and Ahmed, 2002). Chen and Gao (2003) examined that organizational structure dimensions, the size and complexity of departments or divisions and leadership styles and cultures can strengthen governance. The role of rapid advancements in information technology affects governance. The purpose of this study is to understand the Hajj fund governance 's pattern in the Ministry of Religion especially in the BPIH sub-directorate

\section{RESEARCH METHODOLOGY}

This study aims to understand the implementation of governance of Hajj Fund in the Ministry of Religion of the Republic of Indonesia. This research focuses on the pattern of governance of the Hajj funds which at the operational level is the responsibility of the Hajj Fund 
Management Directorate, especially funds managed by the sub directorate of Hajj Implementation Costs or the BPIH sub directorate.This study uses interpretive methods whose purpose is to make everything from life experience and described in depth and meaningful (Denzin, 1989). Ethnomethodology approach is then used to uncover everyday life, namely the study of how a society runs or initiates their culture (Garfinkel, 1967). The data used is the result of interviews with actors in the BPIH sub-district. The interview data is then indexed to find themes. Furthermore, reflexivity, which is a description of the actor's side of the site in this case BPIH sub directorate, is carried out. Then a contextual analysis is performed. Contextual analytical presentation framed with common sense shows a general understanding that is accepted by all group members which are considered to be definite and lead to general cultural patterns in the group or the common culture.

\section{DISCUSSION}

Hajj affairs based on Law no.13 / 2008 are mandated to the Ministry of Religion of the Republic of Indonesia. The public's interest in carrying out the pilgrimage has been growing along with the increasing number of people in the middle class. Long queues appear to reach millions while the hajj quota does not increase. Based on the information from some informants, the waiting period for prospective pilgrims to the holy land get very long because the number of prospective pilgrims who register to perform the pilgrimage to the holy land has not been anticipated. This waiting period has happened since 2008 because the prospective pilgrims needed to wait for only three years in the previous year to get their turn to conduct the pilgrimage. The long queue affects not only the year of the departure but also the growing funds from the initial deposit of the pilgrims.

The initial deposit or deposit system in Islamic banks is done by providing a checking account to help the Ministry of Religion maintain its commitment in carrying out the principle of sharia compliance. The Ministry of Religion made an agreement with the Deposit Recipient Banks that if Rp. 20 billion is collected, half of it (Rp.10 billion) will be deposited directly. Funds for the initial deposit of the pilgrims are carried out by the 'wakalah' contract or deposit funds. Wakalah means prospective pilgrims entrust their initial deposit funds to the State in this case the Minister of Religion to be used optimally in the implementation of the Hajj. The meaning of wakalah is submitting or entrusting something to someone, thus wakalah is an affair that is entrusted (Antonio, Syafi'i, 2008). Wakalah also means at tafwid which means delegating or giving a mandate (Muhammad, 1995). The initial deposit fund is then managed by the BPIH subdirectorate. The informant further revealed that, "In accordance with Law No. 13 of 2008, hajj funds may be developed for three types, namely sukuk, deposits, demand deposits. The type of investment is indeed very limited". The restrictions on financial instruments used are in accordance with the mandate of the law that the Ministry of Religion is only allowed to invest in sukuk, deposits and demand deposits. This is indeed a safe investment method ".

The BPIH budget that has been approved by the Indonesian Parliament and the Ministry of Religion can then be disbursed. This fund is the source of funds managed by the Sub-directorate section of the Development of Hajj funds which initially comes from the deposit funds of the prospective pilgrims. What if the utilization proceeds do not meet the amount of funds for the implementation of the Hajj? The lack of funds is taken from indirect cost funds. This indirect fund is actually the initial deposit fund for pilgrims who have not departed in the next year, which is called direct cost. The funds used to finance the organization of the pilgrimage (BPIH) come from both direct costs and indirect costs. In practice the BPIH fund paid by the pilgrims at the beginning of the initial deposit is only to get a portion, in the year of their departure they must pay off as much as the lack of the large BPIH stipulated by the Ministry of Religion and the Indonesian Parliament. If the Ministry of Religion and the House of Representatives determine the amount of BPIH is Rp. 35 million, then for the initial deposit the pilgrims pay Rp. 25 million, the repayment in the year of departure is $\mathrm{Rp} .10$ million. This repayment varies between regions in Indonesia. A question arising from a number of pilgrims is where does the money go from the 
period of the initial deposit to the repayment of the BPIH? The informant said that the information told to public is only BPIH that is called direct cost paid by pilgrims. While the hajj operational funds are not enough from the direct costs paid by the pilgrims, they must be supported by indirect costs. The informant said that, "This is a mistake. The information that we announced to the public is only from BPIH, here it is termed direct cost paid by pilgrims. As the hajj operational funds are not enough from direct costs, they must be supported by indirect costs. The informant's statement stated that as organizers of the pilgrimage they realized that this term was different from the term that is recognized in accounting.

The amount of BPIH was set in the year of departure and shortage paid by pilgrims, but according to the actor at the BPIH sub-directorate the cost of the pilgrimage reached around Rp 60 million per person. To fulfill the shortage, the optimization fund and the funds of prospective pilgrims who have not departed is used. The informant said that, "The total deposit of the congregation is now around Rp. 38 trillion. Yields obtained by Rp. 400 billion. Within a year the yield funds are used Rp. 3.7 trillion from the existing Rp. 4.8 trillion, which is determined based on the Government's proposal and then approved by the parliamnet of RI". Based on the informant's information, it is known that the initial deposit funds for all prospective pilgrims reached thirty-eight trillion rupiah. Profit sharing funds only reach four hundred billion rupiah in a year. These large funds can be used to cover the shortage of funds for pilgrims who will leave that year. The funds to be used must be based on the agreement of the Parliament of the Republic of Indonesia. The use of hajj funds that have not departed disrupts a sense of justice. However, the actor in BPIH subdirectorate stated that in the calculation of BPIH costs were included which were not directly related to pilgrims. Informants as hajj fund managers agreed to state that the use of indirect funds is indeed very much needed and this is a form of ta'awun or help each other to help fellow prospective pilgrims. Based on the fact that the accumulation of goods especially money is a form of waste. Allah subhanallahuwata'ala ordered that the money and property be utilized as well as possible, should not be wasted in a wasteful manner.

Funds for the initial deposit of pilgrims actually have two types, namely the regular pilgrimage and the special pilgrimage. Special Hajj pilgrims are those who receive a program from Hajj Travel that is licensed and uses a shorter amount of time in performing the Hajj in the holy land. Special pilgrims pay more BPIH than regular hajj pilgrims do. The amount varies depending on the services offered by the Hajj Travel. This is not managed by the Ministry of Religion in terms of its implementation. However, like regular pilgrims, the initial deposit to get the seat number is the same, namely twenty-five million rupiah. The shortage will be paid close to departure and usually in just one or two years. The amount of the initial deposit funds is quite large and mixed with the initial regular pilgrimage deposit funds.Therefore, the deposit funds from a special Hajj are also used as a subsidy fund. Special pilgrims are not informed about it. The informant stated, "... this is funny ... the BPH of Special Hajj income is not returned to special hajj pilgrims but is used for regular Hajj instead. The informant's statement shows that the special pilgrims do not know that their funds are also invested by the Ministry of Religion of the Republic of Indonesia. Special hajj pilgrims do not get living costs in the holy land. The informant's information shows that the prospective pilgrims do not know and are not asked for approval on the payment of their initial deposit funds due to data and communication constraints to many prospective pilgrims. The large number of worshipers and deposits made in several banks throughout Indonesia does not allow to compile all information manually. Technological advancements and the existence of virtual accounts are alternative solutions that can help the Ministry of Religion in informing Hajj funds to prospective pilgrims. Law no. 34 of 2016 requires the use of a virtual account because it is not possible if done manually. Virtual Accounts make it easier for the Ministry of Religion to manage Hajj funds and provide transparency to the public, namely to prospective pilgrims. In fact, this helps prospective pilgrims to ease the burden because of the large opportunity to not pay off the BPIH if the departure waiting period takes a long time. 


\section{CONCLUSION}

The management of the Hajj fund, especially in the system of receiving and optimizing the Hajj funds conducted by Sub directorate BPIH, is by expressing the ta'awun pattern meaning that without the knowledge of prospective pilgrims, both regular and special Hajj. The contract of time when the pilgrims make an initial deposit must be explicit. This has only been implemented for several years. The actor understands that wakalah refers to funds that are entrusted to the Ministry of Religion, particularly BPIH subdir and these funds must be manage prudently. Governance that demands transparency is not done on the grounds that there are many prospective pilgrims and are widespread throughout Indonesia. However, this obstacle will be overcome with a virtual account in the future.

Utilization of hajj funds through subsidies between pilgrims who will depart by using indirect costs from hajj pilgrims whose funds have not yet departed shows a pattern of ta'awun, namely the principle of helping one another as a pilgrim. Approval of the amount of funds to be used is carried out through an open meeting between the Indonesian Ministry of Religion and the Indonesian Parliament as representatives of stakeholders, especially pilgrims. Reporting on the use of the costs of the hajj pilgrimage is reported to get approval as a form of accountability for the use of Hajj funds.

\section{REFERENCES}

Agustianto. 2008 ,Good Corporate Governance di Bank Syariah, Kajian Studi Ekonomi Islam, Menuju Terciptanya Sistem Ekonomi Berdasarkan Syariah Islam, Jurnal Ekonomi Islam no.vii, 2008

Antonio, Syafi'I (2008) Bank Syariah dari Teori ke Praktik, Jakarta: Gema Insani Press

Bahrul, Datuk, (2014), Sukuk, Dimensi Baru Pembiayaan Pemerintah untuk Pertumbuhan Ekonomi, Jurnal Riset Akuntansi dan Bisnis 14 (1)

Benz , Frey. 2007. Corporate Governance: What can we learn from public governance, journal of Academy of Management Review.

Berg, Bruce, 2004, Qualitative Research in Methods for the Social Sciences

Black, B., Olin dan J.M, 2001, The Corporate Governance Behavior and Market Value of Russian irms, Emerging Markets Review, 2, 1-25.

Bovaird, Tony, 2005, Public governance balancing stakeholder power in network society, International journal review of administrative sciences , 71(2)

Cayeros, A. D., Solano, C. E. B., Guadalajara, U. De, Lomelí, E. V., Guadalajara, U. De, Mendieta, M. V.,Carlos, J. n.d.. 2005 . Journal of Public Governance and Policy.

Chapra, M. U, Ahmed. H. 2002. Corporate Governance in Islamic Financial Institutions, Corporate Governance, Islamic Development Bank, Research and Training Institute.

Denzin, N.K, 1989, Interprteive Interactionism, United States of America, Sage Publication, Inc.

Garfinkel (1967), Studies in Etnomethodology, New Jersey, Prentice Hall, Incl 
Gregory, H.J., Simms, M.E. 1999. Corporate Governance:what is and why it matters. In $9^{\text {th }}$ International Anti-corruption Conference (pp. 1-20)

Glynn, J. J., dan Murphy, M. P. (1996). Public management: Failing accountabilities and failing performance review. International Journal of Public Sector Management, 9(5/6), 125-137.

Hadna, Efendi, .2009. Evaluasi kebijakan pemberdayaan masyarakat dalam rangka pengembangan ekowisata di destinasi pariwisata kawasan wisata parangtritis, etc.repository ugm.ac.id

Hasanudin, Amin, "Application of MusharakahMutanaqisah Home Financing As an Alternative to Traditional Debt Financing: Lessons Learned From the U.S. 2007 Subprime Crisis", Journal of Islamic Economics, Banking and Finance,Vol. 9 No. 3, July - Sep 2013.

Hartley, J. (2005) Present Innovation in Governance and Public Services : Past and Present. Public Money \& Management, 25(1), 27-34.

Huang, Zmud, 2010. Influencing the effectiveness of IT governance practices through steeringcommittess and communication polices, European Journal of Information Systems, 19(3).

Huberman, Michaels, dan Miles, Mathew. 1994. Data Managemt and Analysis Methods, Thousand Oak, Sage.

Hood, C. 1995. The New Public management int the 1980s: Variations on a Theme Accounting Organizations and Society ( vol 20, hlm)

IFAC. 2008. Handbook of international auditing, assurance, and ethics pronouncements.

Ibrahim, Manar,(2014), The impact of Organizational Structure on orgaizational commitment: a comparison between public and private sector firms in Jordan, European journal of Business and Management 6(2)

Irianto, Gugus, 2015. Spirit Profetik, Akuntan dan Pencegahan Fraud, PidatoPengukuhanJabatan guru

Ludigdo, U. 2005. Pemahaman Strukturasi atas praktek Etika di sebuah kantor Akuntan Publik. Disertasi, Program Pasca Sarjana Univeristas Brawijaya, Malang.

Muhammad, Abu Bakar, Fiqh Islam, (1995) Surabaya: Karya Abbditama, :hal 163.

Nugroho , Dimas, 2012, Pengaruh komitmen Organisasi, Komitmen Profesional, Konflik Peran, Budaya Organisasi dan Tindakan upervisi terhadap Kepuasan Kerja Auditor, respository. unika.ac.id

Prasojo, Eko, Kurniawan, 2008, Reformasi birokrasi dan Good Governance : Kasus Best Practices dari sejumlah daerah di Indonesia, Prosiding International Symposium of Jurnal Antropologi Indonesia.

Sekaran, Uma. 2010. Research Methodology for Business, John Willey, USA.

Stone, Ostower, 2006, Governance : research trends, gaps, and future prospects, The non profit sector: a research handbook.

Taufik, Kemala, 2013, Pengaruh pemahaman Prinsip-prinsip Good Governance, Pengendalian Intern dan komitmen Organisasi terhadap Kinerja Sektor Publik, Jurnal Pendidikan Ekonomi dan Bisnis 
Torfing, Sorensen, 2009, Making governance networks effective and democratic through metagovernance, Public Administration Journal , 87 (2)

Walace, Peter, Zinki (2004), Corporate Governance : Mastering Business in Asia, Wiley, Atlanta, USA.

Wardani .2011. Tinjauan Hukum Islam terhadap penentuan ujroh pada pembiayaan haji di BNI Syariah Semarang.

Waters, M. 2010. Modern Sociological Theory, London: Sage Publications.

Zimmerman, Jerold. 2001. Conjectures regarding empirical managerial accounting research, Journal of accounting and economics, 32 (1-3)

PP Nomor 17 Tahun 2012 tentang Pengelolaan Dana Haji

Undang - undang Nomor 13 Tahun 2008 tentang Dana Haji

Undang-undang no 34 tahun 2016 tentang Badan Pengelola Keuangan Haji 